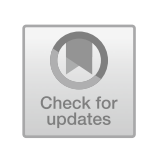

\title{
Towards Being Wounded by Thought: Indigenous Metaphysics Is (Still) Waiting in the Wings of Science Education
}

\begin{abstract}
Any act of reading is besieged and delivered by the precariousness of intertextuality. And translation is, after all, one version of intertextuality... heavy-handedness cannot punctuate an entire text where "penser" (to think) carries within itself and points at "panser" (to dress a wound); for does not thinking seek forever to clamp a dressing over the gaping and violent wound of the impossibility of thought? (Spivak, 1976, p. lxxxvi)
\end{abstract}

While the purpose of this chapter is to conclude this book, how does one go about "closing" a book whose primary task is to unsettle the metaphysics of cloture (i.e., as double(d) closure [verb] and enclosure [noun])? When "each act of reading the 'text' is a preface to the next" (Spivak, 1976, p. xii), a conclusion (as with an introduction; see Chapter 1) must always be open at both ends, provisional, and contingent as "any act of reading is besieged and delivered by the precariousness of intertextuality" (Spivak, 1976, p. lxxxvi). Translating text into the context of (a) conclusion does not necessitate its (whole) surrender to the context: a conclusion remains open to (its own) intertextuality, never (fully) achieving closure. ${ }^{1}$

As Spivak (1976) implicitly asks, how could a conclusion ever achieve closure? The heavy-handedness of the metaphysics of cloture can never fully foreclose the possibility of thought (penser) that confronts from outside the concepts, categories, and constructs that we hold and that

M. Higgins, Unsettling Responsibility in Science Education, Palgrave Studies in Educational Futures, https://doi.org/10.1007/978-3-030-61299-3_8 
hold us. This confrontation always retains the possibility of rupturing the clôture of metaphysics, leaving us wounded by thought (see also Britzman, 2003; Lather, 2007) and (re)opened by that which is to-come. However, this potential is never fully achieved, "for does not thinking [(i.e., penser $)$ ] seek forever to clamp a dressing over the gaping and violent wound [(i.e., panser)] of the impossibility of thought" (Spivak, 1976, p. lxxxvi)? In other words, not all thought (re)opens: thought is, at once, both the possibility of thinking anew and thinking again. As poison and panacea, it is nonetheless a necessary and unavoidable pharmakon: "thinking about science is part of doing science" (Barad, 2000, p. 245). Thinking, both penser and panser, are never disentangled from relationships (e.g., Indigenous science) to-come that vacillate between becoming and unbecoming, being and non-being beyond the cloture of metaphysics (see Barad, 2012a).

Again, even if the metaphysics of clotture is totalizing, it is never totalized: the possibility of being wounded by thought, such as Indigenous science to-come, is always already present. Also, such can also be said for the entangled (neo-)colonial logics by which it is entangled and (co-)constituted. Importantly, such a radical openness is at the core of both Indigenous science and quantum mechanics. It is how relationships are (re)generated through the world's ongoing becoming (see also ApffelMarglin, 2011; Cajete, 1994, 2000; Little Bear, 2016). Further, as Barad (2012a) states, "ontological indeterminacy, a radical openness, an infinity of possibilities, is at the core of mattering" (p. 16, emphasis mine), in both senses of the word (i.e., materializing and coming-to-significance). Accordingly, Kuokkanen (2007) reminds that disrupting and displacing the violence of metaphysical clôture as both process and product, as well as the ontological indeterminacy (rather than epistemological uncertainty; see Barad, 2011) generated by this task are the necessary conditions for the spirit of the gift to circulate, for new relations to be formed and for relations to be formed anew (see also Apffel-Marglin, 2011). For Kuokkanen (2007), such rupturing is in itself a gift, albeit a difficult one. As Indigenous science continues to be, in many ways, considered tocome, ${ }^{2}$ this book centres the invitation to (re)open the spaces of science education (through a double $(\mathrm{d})$ inversion of the gaze back onto itself; see Lather, 2007) so that science education might be wounded by thought and open(ed) to new and renewed relationships to Indigenous science (to-come). 
Thus, the task within this conclusion is not to strive for the "rage for unity" (Spivak, 1976); that is, the tidying up of untimely and disorderly loose ends to achieve the closure typically presumed of concluding. Rather than tuck, trim, and tidy away the partially extended relationalities(-tocome) with which we have journeyed, this chapter is presented as an open-ended conclusion whose possible possibilities also reside in (and beyond) what may have been and what may yet be actualized. Towards this end, this open-ended conclusion explores two parts and processes.

First, I offer a summary and synthesis of the book to highlight the ways in which Indigenous science is to-come. However, this potentiality is not transcendental. Rather, it occurs within relationship, where youthe reader-are entangled (recognizing that the "you" addressed here is subjectively (un)done in material-discursive relations as the languagepractices you possess also possess you). You are encouraged to pay attention to the ways in which thought manifested throughout: (How) Did it wound, allowing for the possibility of Indigenous science to-come (i.e., penser)? (How) Did thought work to cover the wound, leaving Indigenous science as yet-to-come (i.e., panser)?

Second, the notion of being wounded by thought (i.e., penser and panser) is quickly revisited once more to conclude by turning the message of Indigenous metaphysics still waiting in the wings of science education (see Little Bear, 2016) on its head to (re)open this closing with a message of affirmation.

\section{Summary of the Argument so Far (For Readers in A Hurry ... $)^{3}$ : Mapping Pathways Travelled UPON AND ThOSE (YET-)TO-COME}

Because we must begin some-where and some-time, let's begin by recapping the central premise of this book ${ }^{4}$ : working towards the radical potentiality of thinking (penser) Indigenous science within the context of science education, rather than upholding thinking (panser) that, through foreclosure, excludes, differs, and defers Indigenous science. This matters as, currently and often within science education, Indigenous science is either excluded or included in ways that differ from or defer its intended meanings, as well as its pedagogical potentiality for all students. As the goal of science-education-as-usual is to bring students to know what 
scientists know (i.e., scientific facts) or enact how scientists know (i.e., scientific methods), science education often continues to naturalize and normalize the subject position of "scientist" which is emblematic of the masculine, Eurocentric, and anthropocentric subject of Western modernity. When presented as the (only or most valid) way-of-knowing-Nature, students' learnings are perpetually inflected and inflicted by the ways in which (neo-)colonial logics and Western modern metaphysics (fore)closes the possibility of being and becoming otherwise. The most significant consequence of this is that "school science" potentially produces experiences of cultural assimilation and acculturation rather than enculturation for the vast majority of students (i.e., 90\% of students, see Aikenhead \& Elliot, 2010). However, for students whose daily lived experiences continue to be negatively impacted by Eurocentrism (re)produced with/in (and beyond) science education, learning with/in the cultural practice of "school science" largely continues to be a form of epistemic violence (Bang \& Marin, 2015; McKinley, 2001, 2007).

As such, the questions engaged herein are not those of empowering those excluded from science to participate, particularly if the culture of science and school science remain unperturbed by the effort. As Kuokkanen (2007) reminds, such efforts can be "more patronizing than helpful and... do not lead to any real transformation" (p. 152). Rather, after Kayumova, McGuire, and Cardello (2019), this book embraces a recent move in science education "from empowerment to responseability" (e.g., de Freitas, Lupinacci, \& Pais, 2017; Higgins \& Tolbert, 2018; Wallace, Higgins, \& Bazzul, 2018). This is particularly significant given the stakes: science education makes palatable and possible the ongoing dispossession and devastation of Indigenous Land, as well as erasure of Indigenous peoples (Bang \& Marin, 2015). One more time: science education has a responsibility, but is it able to respond?

Towards this end, the central question guiding this entire inquiry has been how is Indigenous science to-come with/in the context of science education? Recall that this central question is understood and has been explored in through three guiding inflections that are inseparably entangled. First, to-come continues to signal that Indigenous science, in the context of science education, has not yet (wholly) arrived. Secondly, to-come signals ethical indebtedness: How might the structure, culture, and discipline of science education be (re)opened and re(con)figured to receive Indigenous science to-come, on its own terms, and in ethical relation? Thirdly, to-come entails a responsibility (and response-ability) for and towards that which is 
to-come: What types of practices might allow for and nurture the possibility of Indigenous science to-come?

While Indigenous science is still to-come-in all three inflectionsupon conclusion of this book, ${ }^{5}$ I continue to be driven by the goal of exploring what possibilities are made possible through the labour of attempting to be response-able and accountable (see Barad, 2010) to Indigenous metaphysics waiting in the wings. As a means of responding to this guiding question and goal, I translate the pathways ${ }^{6}$ of science education journeyed upon in each chapter into the format of a rough sketch. ${ }^{7}$ These sketches offer a synthesis of Indigenous science to-come in one or more of its inflections, as well as an overview of the chapter contributions to the field of science education. Further, the deconstructive methodologies employed throughout the book will be revisited for their significance with respect to the larger project of unsettling science education. ${ }^{8}$ As these sketches are enactments, they are mappings that are meant to invite relation as living, breathing concepts rather than (re)tracings who are epistemologically and ontologically foreclosed through representationalism.

\section{Chapter 1: Unsettling Metaphysics in Science Education}

The trailhead of this journey introduces and frames the simultaneously co-constitutive and othering relation between Western modern science and Indigenous ways-of-knowing-in-being as it manifests within spaces of science education. This chapter asks: What does metaphysics (i.e., the co-constitutive space of epistemology, ontology, ethics, among others) have to do with science education and the ways in which Indigenous science remains (yet-)to-come? And provides multiple tools to equip oneself for the remainder of the journey. Most notably, unsettling science education is presented as a double(d) approach to address the ways in which settlercolonial logics linger and lurk within and as sedimented and stratified knowledge-practices (Bang \& Marin, 2015; Bang, Warren, Rosebery, \& Medin, 2012). As a more nascent approach to the question of Indigenous science within science education, this work is supplemented by two larger orientations that address its double(d) meaning. The first orientation addresses settler colonialism by providing an overview of similar yet different pathways explored with/in science education: decolonizing (e.g., Aikenhead \& Elliot, 2010; Chinn, 2007) and post-colonial (e.g., Carter, 2004; McKinley, 2007) approaches to science education in response to the metaphysics of modernity. In particular, this overview 
maps the ways in which Eurocentrism operates (e.g., mis- and underrepresentation, deficit thinking, universalism) and how decolonizing and post-colonial science respond through curricular deconstruction and reconstruction. Accordingly, the second orientation addresses settled meanings. It unpacks deconstruction (e.g., Spivak, 1976) in relationship to decolonizing methodologies, as well as decolonizing science education, as a (meta-)methodological approach to (re)open the metaphysics of modernity. Of particular importance to this book is the displacement and disruption of the self/other, nature/culture, and ethical possibility/impossibility binaries. Importantly, this sets the stage for bearing witness to the ways in which settler coloniality often manifests as absent presence and to (re)open the space of response within science education towards Indigenous ways-of-knowing-in-being.

While this first chapter's primary purpose is to provide a general orientation for the work that is to come within the remainder of the book, a significant contribution that emerges is (re)positioning decolonizing science education at the ontological turn (e.g., Kayumova et al., 2019; Higgins \& Tolbert, 2018). The critical call to decolonize has been primarily taken up by extending the openings produced through treating both science, and science as problematic cultural spaces, to be examined through socio-cultural approaches (e.g., sociology of science). As cultural and socio-cultural approaches offer both methodological possibility and problematic when they interface with the metaphysics of modernity (see Carter, 2010; Latour, 1993), moving towards ontological plurality ${ }^{9}$ and deconstructing ontology-as-usual (i.e., Cartesianism) (re)opens the conversation beyond the question of which epistemology best fits the ontology of Nature.

While there is no specific deconstructive practice conceptually sketched out within this chapter, to introduce deconstruction into a field where it is under-employed and -explored bears significance. In turn, this contributes specifically to a small yet growing body of research that engages in (mis)reading science education texts for their settled (neo-)colonial referents (e.g., Carter, 2004, 2005; McKinley \& Aikenhead, 2005). Further, these insights are employed to frame de/colonizing in a fulsome way within the field of science education ${ }^{10}$ to make explicit the ways that ways in which decolonizing and colonizing discourses cannot be wholly framed in opposition as they are always already co-constitutive (e.g., (neo-)colonial logics even seep into decolonizing efforts). 


\section{Chapter 2: The Homework of Response-Ability in Science Education}

Continuing to journey with the insight from the previous chapter that science education has a responsibility towards Indigenous science (tocome) as the result of its exclusionary practices rooted in Eurocentrism and (neo-)colonialism, this chapter engages with the differential question of the degree to which science education has the ability to respond towards Indigenous ways-of-living-with-nature (IWLN) and traditional ecological knowledge (TEK). Through revisiting a significant personal pedagogical encounter (see Higgins, 2014), I make the case that having a responsibility and being able to respond are not one and the same, particularly when the very systems that exclude Indigenous science (e.g., Eurocentrism) (fore)close the ability to respond as well as how we come to understand responsibility.

Thinking with the work of Sami scholar Rauna Kuokkanen (2007, $2008,2010)$, attention is brought to unsettle responsibility: disrupting and displacing the ways in which responsibility is often and inadvertently overcoded by the (neo-)colonial logics that it sets out to refuse and resist as the result of epistemic ignorance. ${ }^{11}$ Significantly, epistemic ignorance is not strictly a lack of knowledge-it can also be the result of knowledge that acts as resistance, which (fore)closes the possibility of knowing otherwise (Kuokkanen, 2008). For there to be responsibility, there must be an ability to respond: there is a "homework of response-ability" required to (re)open the norms of responsiveness towards the possibility of heeding the call of Indigenous science from within the structure of science education (see Kuokkanen, 2007, 2010). The "home" part of homework can take many meanings: home as cultural, disciplinary, geographical, historical, epistemological, and ontological, among others. The "work" part involves coming to understand how these multiple "homes" foreclose the ability to respond to Indigenous science to-come).

The most significant contribution to science education from this chapter is the translating of Kuokkanen's (2007) homework of responseability for the context of science education. While it is not new to study the "home" of this field (be it historical, philosophical, cultural, or other), Bazzul (2017) suggests that this homework is rarely employed to put science education back into its contemporary context: "science education seems to ignore the social, historical, and political realities that give shape to its practices, knowledges, and literatures" (p. 67). Significantly, the homework of response-ability is not only a call for engaging with the ways 
in which science education is always already a situated knowledge (see van Eijck \& Roth, 2007), but that its multiple and co-constitutive homes are rich sites for critical labour, such as (re)opening science education to Indigenous science to-come. In turn, as many of science education's multiple homes are absent presences which are often sedimented and stratified, as well as locations in which (neo-)colonial referents linger and lurk, the homework of response-ability is also the primary deconstructive tool put to work and offered by this chapter to unsettle science education.

\section{Chapter 3: Serious Play: Inflecting the Multicultural Science Education Debate Through and for (Socratic) Dialogue}

Wandering through the pathway(s) presented by the multicultural science education debate, the most glaring feature of the scholarly literature is strongly conflicting epistemic demands on "what counts" as science (and in turn school science curricula) and respectful education within multicultural science education classrooms (see Lewis \& Aikenhead, 2001; McKinley \& Stewart, 2012; van Eijck \& Roth, 2007). At stake is the inclusion of TEK and IWLN alongside WMS. This highly contested commitment and practice nearly (wholly) polarizes the field, resulting in two seemingly diametrically opposed positions. Cross-culturalists advocate for the inclusion of TEK and IWLN on the basis that they are equally (but not similarly) valid; universalists do not consider these placed-based waysof-knowing- nature as equally valid to the "universal" standard of WMS. These positions directly impact conceptions and enactments of respecting and including diverse knowledge traditions that students bring and, in turn, students themselves.

Mapping the contours of the path, the culture of the debate can be said to deploy both dialectic negation (see Bohm, 1996), as well as adversariality (as method; see Moulton, 1983). This regularly brings the potentiality and possibility of creative movement through the field of science education to a viscous stasis, although never achieving a grinding halt. On this note, Southerland (2000) commented early on that the multicultural science education debate was, "generating a lot of heat, but very little light" (p. 289). While the critical task of addressing conflicting values "head on" is a one of necessity and importance, the literature seems to indicate that changes through current modes of engagement have been, and continue to be, slow and partial. This invites an important question that is revisited in many ways throughout the book: How might 
coming at these issues of metaphysical closure and seemingly sedimented knowledge-practices sideways and obliquely provide new (re)openings?

A central contribution to science education that is produced through this chapter is (re)considering the multicultural science education debate obliquely through its antagonism. While I am not the first and likely will not be the last to consider the antagonistic nature of the multicultural science education debate (e.g., McKinley \& Stewart, 2012; van Eijck \& Roth, 2007), putting theories, strategies, and practices of conflict resolution to work are notable (e.g., dialogue; see Bohm, 1996). A multiplicity of tools, practices, and considerations are provided for attending to, and reconfiguring, the (re)production of adversariality. These include consideration of meaning-making as relational and embodied (e.g., paying attention to emotions and physical responses as indicators of the movement of thought), as well as seeking out shared meanings as productive pathways and paths of lesser resistance. Examples of shared meanings sought in Chapter 3 include knowledge as knowledge-practice (van Eick \& Roth, 2007); and knowledge-practices as epistemologically situated (van Eick \& Roth, 2007), ontologically situated (Cobern \& Loving, 2008), and culturally hybrid (van Eijck \& Roth, 2009).

The deconstructive tool put to work within Chapter 3 was the play of (re)signification. As the first of many deconstructive strategies employed and leveraged throughout this book, the play of (re)signification invites the reader to consider the ways in which textual realism (i.e., representational fidelity; see Carter, 2004) is a cultural myth that diverts and at times disallows the wandering of the pathways of science education otherwise.

\section{Chapter 4: Mirrors, Prisms, and Diffraction Gratings: Placing the Optics of the Critical Gaze in Science Education Under Evasure (After the Critique of Critique)}

Following the orientation provided by the trailhead of Chapters 3 and 4 asks if the metaphors through which the field of science education critically engages are (re)shaping the possible pathways for, and waysof-navigating, inclusion of Indigenous science. (Re)considering critique within this chapter began with the notion that critique-the conventional mode through which the culture of dominance (e.g., Eurocentrism) within science education is challenged-has run out of steam (Latour, 2004a). As Latour (2004a) states, the very tools employed by critics have been appropriated by those who have been and continue to be its 
intended targets. As such, critique is easily reversed and brought to a standstill (as evidenced within Chapter 3 ). Thus, critique becomes protective (of positions, concepts, and categories) rather than productive (in seeking shared meanings) (see Spivak, 1976), unfortunately contributing to the (re)production of Indigenous science as yet-to-come within science education (see McKinley \& Aikenhead, 2005; see also Kuokkanen, 2007; Spivak, 1994).

Critique (in the conventional sense) is meant to (re)open possibilities for knowing and being otherwise. However, it presents itself as already prescriptive as a result of proposing particular ways of navigating its pathways. Such operationalization of critique enacts and upholds the very metaphysical structures worked against within this book. Critique-as-usual (re)naturalizes many of the tools and strategies of (neo-)colonization and cloture (e.g., distance, separation, hierarchy, sameness/difference). Nonetheless, critique should not, and cannot, be dismissed. Its role continues to be central and critical in terms of (re)opening possibilities for Indigenous science to-come.

Considering critical engagement as epistemologically situated and metaphorically mediated allowed for the possibility of it to become otherwise. Approaching conventional critique as mirrored correspondence (see Barad, 2012b; Latour, 2004a) opened up space to differently journey the path of critique. This entailed contemplating optical metaphors whose differential metaphysics might allow: (a) Indigenous science (to-come) to be more intelligible from within spaces of science education; (b) for the potential to reveal, as well as displace, (neo-)colonial structures and strategies that (re) centre WMS (both implicitly and explicitly); and, (c) for the production of differential modes of critique that might be more productive in being response-able and accountable towards Indigenous science to-come.

Through deconstructive (mis)reading, what science education is (e.g., critique as mirrored correspondence) was substituted with what it is (not) (e.g., Foucaultian prismaticity, Baradian diffraction). Such deconstruction works to displace and disrupt, all the while upholding the structure one is working within. The re(con)figured practices of critique (i.e., prism and diffraction grating) differentially reveal otherwise taken-for-granted concepts, categories, knowings, and beings operating with/in multicultural science education. ${ }^{12}$ These optical metaphors present unique contributions to the field. As Bazzul and Carter (2018) state in their literature review of Foucaultian application in science education, there are but 
a few examples of Foucaultian critique within science education in general and, I would suggest, much less with respect to the particular context of Indigenous science. Inclusion of diffraction grating as critical metaphor is all-the-rarer as Barad's (2012b) articulation of diffraction as critique is but recent, and the ontological turn only beginning to bear upon science education (see Milne \& Scantlebury, 2019).

\section{Chapter 5: Tinkering with/in the Multicultural Science Education Debate: Towards Positing an(Other) Ontology}

The continued excursion through science education presented with/in Chapter 4 entails wandering the pathways of multicultural science askew and obliquely by considering uncommonly considered, but ever-present, ontology. Journeying with insights garnered from the previous chapters reveals that ontology as singular, naturalized, and taken-for-granted comes to bear on the ways in which Indigenous science is to-come. In short, ontology at once acts as the handmaiden of Eurocentric and the (cultural) meter stick through which epistemological realism (i.e., the epistemology of WMS) is upheld and (re) centred. Here, Cobern and Loving's (2008) call for ontological situatedness as a means of resolving the multicultural science education debate simply displaces the terms (e.g., presenting WMS as universal) rather than disrupting them: alignment assumes and presupposes separation and separability, as well as requires mirrored correspondence (extending Chapter 3's metaphor of the critical mirror).

By extending critical alternatives from the previous chapter, science education is (re)opened to a differential consideration of ontology. They include: (a) ontology as plural rather than singular; (b) ontology as a metaphysical choice rather than pre-supposed; and (c) the situation where the aforementioned ontological conditions are cuts one colludes in making, and such metaphysical choosing (re)opens ontological agency to one's (distributed) ethical responsibility (see Barad, 2007). This invites the positing of an ontology and may begin by naming ontology, and produce movement towards accounting for and being accountable to what is produced and producible within the (never-fully-stable) ontology of teaching, learning, and meaning-making with/in science education.

The deconstructive practice of tinkering (i.e., using tools intended for other tasks) utilized in Chapter 5 invites the reader to pay attention to 
the ways in which the ends and the means never fully coincide. One such consideration that is noteworthy is how tinkering asks for attention to practice, particularly those that get labelled as non-practices (see Spivak, 1976, 1988, 1993/2009). A highly significant example here is the enactment of ontology as practice (see Barad, 2007, 2010; Cajete, 1994, 2000), rather than pre-supposed.

\section{Chapter 6: Positing Cartesianism as an Ontology Within Science Education: Towards a More Response-Able Inheritance with Dr. Frédérique Apffel-Marglin}

Chapter 6 extends the wanderings presented in Chapter 5 through continuing the work of tinkering within what it means to posit an ontology. Particularly, it explores what it might mean to position Cartesianism-the ontology of WMS - as an ontology in order to account for and be accountable to what it produces and makes producible. A series of expert interviews with Dr. Frédérique Apffel-Marglin reveals that Cartesianism came to be operationalized in sixteenth and seventeenth century modern Europe as the result of a confluence of inseparable forces: economy, geography, military, politics, religion, as well as science. These inseperable forces come to constitute $a$ metaphysics of clôture which, there-then, created multiple forms of separation and separability. Notably, for the status of Indigenous science to-come, is the separation (and distance) produced between people who worked the land as knowledgepractice, from the land (i.e., the commons) and the knowledge-practices that were enacted through the spatial-economic practice of the enclosure (see Apffel-Marglin, 2011). Furthermore, through the birth of the laboratory and its associated technologies (e.g., modest witness in concert with other forces), science comes to be constructed as $a$-cultural and a-political, etc; it appears to transcend bias. Considering diffraction invites attention to the ways in which these there-thens transposed into here-nows, as well as the (neo-)colonial knowledge-practices through which this multiplicity of entangled knowledge-practices have been diffused and distributed (see Battiste, 2005; Blaut, 1993; Spivak, 1999).

While the contributions of this chapter are multiple given Dr. ApffelMarglin's expertise on the "birth of modernity", as well as why the metaphysics of modernity is a significant location to labour in accounting 
for and being accountable to Indigenous science to-come, I wish to highlight two orientations to decolonizing and post-colonial science education that diffractively emerge from this series of expert interviews. The first is the importance of privileging transdisciplinarity (see also Battiste, 2013; Smith, Maxwell, Puke, \& Temara, 2016). Science, science education, and Indigenous science (to-come) are irreducible, always failing to fit within a single discipline. While this is a well-recognized quality of Indigenous ways-of-knowing-in-being (e.g., Battiste, 2013; Cajete, 2000; Smith, 1999/2012; Smith et al., 2016), science and science education are more likely to be framed with/in disciplinary logics (as a form of discipline, through the logics of self-sameness and not-otherness). Remaining open to knowledge outside of one's disciplinary tradition is not only an ethical move, but it is also one that is productive as knowledge-practice (see Bazzul \& Carter, 2018). To follow the lived life of concepts and categories into other spaces allows one to consider their differential being and becoming (e.g., Battiste, Bell, Findlay, Findlay, \& Henderson, 2005). Tinkering, as leveraging the un/common, is a remarkable practice of pursuing this productive supplement.

The second orientation, related to the productive supplementarity of transdisciplinarity, is considering the multiplicity of ways in which the metaphysics of individualism work to separate and make separable ecologies of relationships, as well as the ways in which they (inseparably) complement one another. One of the ways that this can be put into practice is, as signalled on the first page of the introduction, by considering entanglements and ecologies of relationships as extending beyond a herenow to a multiplicity of there-thens. In turn, the move towards Indigenous science to-come cannot and should not be considered a response to curricular place-less-ness, but rather place-full-ness. While place may not considered through an Indigenous sense of place, or even actively considered at all, place (i.e., proximal Nature-Culture, space-time-mattering) is never absent: place has its own agency that always comes to bear (see Barad, 2010; Cajete, 2000). The question of place becomes which place comes to bear (as well as when, where, and how)? As demonstrated within Chapter 6 (and introduced in Chapter 3), dominant conceptions of knowing Nature cannot be so easily disentangled from a laboratory there-then, which always already comes to bear on a here-now. To (too easily) suggest a conception of place without attending to the ways in 
which Nature-Culture already comes to manifest runs the risk of masking the workings of power (see McKinley, 2001).

While there are a few deconstructive tools put to work within this chapter above and beyond tinkering, diffraction as methodology is worth highlighting. As means of "reading insights through one another" (Barad, 2007 , p. 30) to account for and be accountable to patterns of difference that are produced, diffraction was an invaluable tool to reveal the ways in which seemingly disparate historicities are always already entangled within contemporary science education: it is to do the (home)work of inheritance (see Barad, 2010; Derrida, 1994/2006). Again, this bears significance as concepts and practices from the ontological turn, particularly those that are methodological rather than substantive, are only beginning to gain traction within science education (see Milne \& Scantlebury, 2019).

\section{Chapter 7: Response-Ability Revisited: Towards Re(con)figuring Scientific Literacy}

As the logics through which the metaphysics of modernity are (re)produced are circular, walking the pathways of science education may often feel as though it is a form of déjà-vu-although what seems as sameness is always already differential. In turn, breaking from modernist orbits requires sustained and focused efforts to work against slippage into processes through which (neo-)coloniality is maintained (e.g., the dialectic negation of othernesss). Nakata's (2007a, 2007b) concept of the cultural interface provides a rich lived-conceptual location from which to consider the multiplicity of conflicting, contradictory, and co-constitutive interactions that occur between Indigenous metaphysics and the metaphysics of modernity. While such circularity is a boon, it is also a gift: resistance to dominance can happen in (almost) any location through which power circulates. This is, of course, with the cautionary note that not all locations are equally productive, and that some locations are a privilege to inhabit even if inhabitation is critical (see Spivak, 1988). Furthermore, not all locations are equally pliable and pry-able.

To be responsible for the complex nature of the culture interface, one needs to be able to respond, to be response-able (see Kuokkanen, 2007; Spivak, 1994). However, to be able to respond to that which is to-come requires that one be able to respond to that which one does not already know (Barad, 2010). Stated otherwise, one must be wounded 
by (the impossible) thought (i.e., penser) and forego the urge to clamp a dressing over the wound (i.e., panser). To work the possibility of getting lost beyond the circularity of the pathways of science and to be wounded by thought, I targeted a location that is central to science education; one which displayed indeterminacy, thus making them pliable and pry-able and open to response-ability as deconstruction: scientific literacy. Significantly, scientific literacy is a sedimented location which (re)produces settler colonialism (see Sammel, 2009): unsettling is indispensable. (Re)opening scientific literacy to other possibilities of "literacy" that work towards plurality and dialogue (i.e., not needing to negate other forms, but rather to situate them): agential literacy and ecologies of relationships (i.e., an Indigenous "sense of place"). Both of these productive (mis)readings allow for the possibility of responding to forms of Indigenous science that are often to-come: community as more than a collection of individuals (which extends beyond humans), other-than-human agency, and non-linear temporalities (see Cajete, 1994, 2000).

The primary deconstructive tool employed within this chapter is response-able reconstruction, which takes seriously the notion that deconstruction and reconstruction are neither separate nor separable (see Jackson \& Mazzei, 2012). Rather, drawing from Barad (2010), responseable reconstruction is a recursive, iterative, and co-constitutive process which stems from the possibilities that arise from the relationality between the two. Notably, it is a practice of re(con)figuring which can productively leverage the openings generated by homework of response-ability towards enacting science education otherwise.

\section{An Open-Ended Conclusion: Indigenous Metaphysics Is (STILL) Waiting in the Wings of Science Education}

This book is now reaching its close. Indigenous metaphysics is still waiting in the wings of science education, and is neither wholly nor hospitably received on the main stage of science education. Nonetheless, I conclude with a message of affirmation. What appears as a partial absence is not lack, a mere criticism, nor a critical negation. Rather, it is a potential relationality, a co-constitutive moment, and movement to-come. 
As Barad (2012a) suggests us in What is the measure of nothingness?, even nothingness is itself is a doing that is rife with possibility and potentiality. This is even the case for what is classically understood as "pure" nothingness: the vacuum of space. As she states,

From the point of view of classical physics, the vacuum has no matter and no energy. But the quantum principle of ontological indeterminacy calls the existence of such a zero-energy, zero-matter state into question, or rather, makes it into a question with no decidable answer. Not a settled matter, or rather, no matter. And if the energy of the vacuum is not determinably zero, it isn't determinably empty. (Barad, 2012a, pp. 8-9)

Rather than this determinability being a question of epistemological uncertainty, it is one of ontological indeterminacy, "the indeterminacy of being/non-being, a ghostly non/existence" (Barad, 2012a, p. 12, emphasis in original). Even the smallest of particles vacillates between being a something and a nothing. It is rife with potentiality as it is never "just itself"; it is co-constituted and co-constituting a plurality of other particles and particles-to-come. As she states, "even the smallest bits of matter are an enormous multitude. Each 'individual' is more up of all possible histories of virtual intra-actions with all Others. Indeterminacy is an un/doing of identity that unsettles the very foundation of non/being" (p. 15). This has consequences for ethics (as co-constituted by epistemology and ontology, of course): "individuals are infinitely indebted to all Others, where indebtedness is not about a debt that follows or results from a trans/action, but rather, a debt that is the condition of possibility of giving/receiving” (pp. 15-16).

As Indigenous science already displays and has always deployed "ingenuity, creativity, resourcefulness, and ability of people to learn and to teach a harmonious way of existence with Nature" (Cajete, 2000, p. 78), the possibility of hospitably receiving Indigenous science is not only an ethical call; science education can learn much from Indigenous ways-ofknowing-in-being and its practices of relational balance, (re)generation, and renewal. Thus, wandering the pathways of science education to heed the call of Indigenous science to-come matters even if it is but a possible possibility: "matter is never a settled matter. It is always already radically open” (Barad, 2012a, p. 16, emphasis mine). Nature (i.e., space, time, matter) is and was never fully totalized within (neo-)coloniality. It is with hope and affirmation that I end: Indigenous science is still yet-to-come. ${ }^{13}$ 


\section{Notes}

1. In other words, the task of a conclusion is "daring to repeat the book and reconstitute it in another register" (Spivak, 1976, p. xii); it is an audacious yet impossible act of translation. As Derrida (1976) reminds more generally, translation is never fully achieved or achievable: meaning is always differed and deferred. Just as there is no originary text there can also be no terminal form of textuality; "there is no exception to this rule" (Spivak, 1976, p. xii), even when presented otherwise. Importantly, this perpetual (re)opening relates explicitly to questions of science education's ability to receive Indigenous science to-come on its own terms: "the question of hospitality begins with the question of translation" (Kuokkanen, 2007 , p. 137). Importantly, translation is both possibility and problematic: it is at once the grounds for dialoguing across difference and, yet, "hospitality is not possible when the guest is required to speak the language of the host" (Kuokkanen, 2007, p. 76). This becomes all-the-more significant when the (neo-)colonial demands of translation make it such that the effort of putting knowledge-practices into relation (re)produces the erasure of Indigenous peoples, places, and practices. Accordingly, there remains the need to be hyper-vigilant in the work of leveraging the productive $\mathrm{im} /$ possibilities of translation in creating spaces of dialogue between Indigenous science to-come and WMS within science education (see also Ahenakew, 2016; Higgins \& Kim, 2019).

2. It bears repeating: the notion of to-come says more about the inhospitability of science education than the ways in which Indigenous peoples have been practicing ways-of-living-with-Nature since time immemorial. This is to say that Indigenous science remains "waiting in the wings" of science education.

3. A conclusion is conventionally (and often conveniently) the end or finish of a given task, event, or process: it often synthesizes what has already come. While conclusions hold the potentiality for a differential engagement with that which has preceded it, they can also work to (fore)close the possible possibilities of meaning-making. In turn, I borrow Latour's (2004b) cheeky formulation of a conclusion as a "summary of the argument (for readers in a hurry...)" (p. 231). While conclusions hold the potentiality for a differential engagement with that which has preceded it, they can also work to (fore)close the possible possibilities of meaning-making.

However, given the contemporary pressures of educational institutions which are often busy by design (and all-the-more-so for those who individually do the work of being the bridge over the gaping disjuncture between commitments to diversity and how inclusion is enacted), the above is not 
an individual(istic) admonition. Rather it is an invitation: as the temporality of reading and writing is forever askew (see Spivak, 1976), it is an invitation to work backwards and outwards to the texts most relevant and pressing.

4. One final time (for those reading from front-to-back), the mantra of beginning some-where and some-time is not only a persistent reminder that we are always already within the question of Indigeneity within science education, but also an invitation to address it as such. To "begin" as if nothing has been done is a form of know-nothing-ism which serves to mask power with innocence, and obscures: (a) the multiple and ongoing responses articulated and practiced within science education for the last few decades; (b) that Indigenous peoples are the most researched peoples in the world; and, (c) that science's Othering of (and, in turn, coconstitution by) Indigeneity irreducibly places the two in relation of obligation. This is to state that science education has a responsibility: one that is to the Other rather than for the Other. The distinction here is not semantic: a responsibility to is to be accountable and answerable to the ways in which Othering has occurred, rather than enacting a form of responsibility-as-usual which leaves (neo-)colonial forms of power stratified and sedimented (see McKinley, 2001). Hence the question: science education has a response-ability, but is it able to respond?

For readers beginning at the end, Kuokkanen (2007) suggests that there is homework to be done:

The academic responsibility for doing homework on [I]ndigenous epistemes must begin at an even more elemental level than examining one's beliefs, biases, and assumptions. It must start with the acknowledgement that the "[I]ndigenous" exists, be it in terms of peoples, their epistemes, or how they have been configured in the geopolitical past and present. (p. 115)

(Re)opening responsiveness requires doing a creative excavation of the multiple ways in which the home of science education (e.g., cultural, disciplinary, geographic, historical) differs and defers the possibility of hospitably receiving Indigenous science. However, as Kuokkanen (2007) emphasizes, this critical and creative work can only begin once we have accepted the existence of Indigenous science or ways-of-living-with Nature.

5. It can be, and has been stated that the possibility for Indigenous science to (wholly) arrive on its own terms and in ethical relation is an impossible possibility in this contemporary moment (see Carter, 2004; McKinley \& Aikenhead, 2005). 
6. After Cajete (1994), we are encouraged to (re)consider science education as a journeying of pathways. This is subtle deconstructive prompt that is significant in three major ways. First, it addresses the (neo-)colonial desire for representation: what might appear as a sedimented and stratified path is inseparable from its enactment, its journeying, its way. Secondly, journeying the path denaturalizes it as it is and can never be the same times: a pathway of science education comes to reveal itself as but $a$ path, (re)opening up a multiplicity of ethical possibilities. Lastly, such tactical insights provide direction for strategically straying off the beaten path or taking the pathway in unintended ways to lose sight of the prescriptive and often problematic ways in which the path is regularly travelled.

7. This partial account is not only a textual strategy to present future orientations and possibilities offered by the work within this book, but also whose incompleteness is meant as gift: presenting an account rather than the account invites orientations to continue wandering the pathways of science education rather than destinations which one accepts or rejects (i.e., science $i s$ or is not this).

8. The significance of deconstruction in science education cannot be understated. It is a form of methodological engagement that allows for the possibility of (re)opening science education towards Indigenous science to-come by identifying and tinkering with/in the structure of education, between what it $i s$, is not, and could be(come); as well as (mis)reading science education for its subtle and lingering (neo-)colonial referents and enactments. Despite its significance, deconstruction is rarely seen at this intersection, despite calls for its use in science education (e.g., Carter, 2004; McKinley \& Aikenhead, 2005), science studies (e.g., Barad, 2010; Latour, 1993), as well as in spaces of Indigenous education that overlap with decolonizing and post-colonial science education (e.g., Battiste, 2013; Cajete, 1994; Donald, 2012).

9. Significantly, as there has been much learned from approaches that diligently study and critically interrogate the culture of science and school science, moving towards ontological plurality does not require the doing away of culture, nor its politics.

10. Notably, this framing significantly extends de/colonizing's introduction elsewhere for science education (i.e., Higgins, 2014), and situates it within a larger conversation which was already ongoing (e.g., Rhee \& Subreenduth, 2006) and provides a richer theoretical context between the decolonizing and post-colonial theories that inform it.

11. For example, the taken-for-granted Western notion of responsibility doubly individualizes responsibility by making responsibility an individual affair and rendering the individual the adjudicator of whether responsible 
action has occurred or not. Such becomes problematic when epistemic ignorance renders the possibility of accounting for and being accountable to one's own actions murky and diffuse (i.e., individuals who perceive their actions as not being oppressive are often also the final arbiter of such within conventional notions of responsibility; see Kuokkanen, 2007). In turn, unsettling response-ability entails decentering the individualistic subject of responsibility to engage with the larger questions of how this "I" is shaped (i.e., the homework of response-ability). Moving beyond the "I" as the ethical subject means considering the ability to respond as being more than an individual affair (without excusing the "I" from responsibility): responsibility must be more than a self-accounting for individually doing or having done the right thing.

12. Furthermore, such metaphors invite a critical suspension (see Bohm, 1996; Foucault, 1997). As some of the issues facing the place of Indigenous science within school-based science education has been differentially (re)produced for decades now (McKinley \& Stewart, 2012), it may be worth considering momentary suspension towards displacing (rather than attempting the impossible and never achieved destruction) of dominant logics (despite seeming counter-intuitive to pause amidst this critical contemporary moment in which Indigenous science is yet-to-come) (see also Patel, 2016; Stengers, 2018).

13. As this conclusion, like all conclusions, is always already an introduction, a supplement that escapes the structure which may be unintelligible as such and yet-to-come, I subtly offer an invitation here, in the margins. As Derrida (1976) suggests, "thought is ... the blank part of the text" (Derrida, 1976, p. 93, emphasis in original); this "closing" is also an opening. You are invited to critically create conditions for students and for yourself to pedagogically be wounded by thought (i.e., penser): to think Nature beyond the metaphysics of modernity through which the wound of knowing nature is bandaged closed (i.e., panser). However, it bears repeating one last time that one cannot be wounded by thought (penser) if the wound is already ( $\mathrm{ad}$ )dressed (panser): responding to world beyond oneself requires that the world not be (fore)closed prior its encounter (see also Spivak, 1999). To engage in the homework of response-ability is to engage in the necessary (re)opening the possibility of being wounded by thought by addressing the ways in which the multiplicity of "home" in homework is (fore)closed to its (co-)constitutive otherness. All of this, to engage with and tell stories that Nature (i.e., space, time, matter) might tell (with) us as a community of learners, were we able to listen anew through different attunement (see Barad, 2007; Cajete, 2015). 


\section{REFERENCES}

Ahenakew, C. R. (2016). Grafting Indigenous ways of knowing onto nonIndigenous ways of being. International Review of Qualitative Research, 9(3), 323-340.

Aikenhead, G. S., \& Elliot, D. (2010). An emerging decolonizing science education in Canada. Canadian Journal of Science, Mathematics and Technology Education, 10(4), 321-338.

Apffel-Marglin, F. (2011). Subversive spiritualities: How rituals enact the world. New York, NY: Oxford University Press.

Bang, M., \& Marin, A. (2015). Nature-culture constructs in science learning: Human/non-human agency and intentionality. Journal of Research in Science Teaching, 52(4), 530-544.

Bang, M., Warren, B., Rosebery, A. S., \& Medin, D. (2012). Desettling expectations in science education. Human Development, 55(5-6), 302-318.

Barad, K. (2000). Reconceiving scientific literacy as agential literacy. In R. Reed \& S. Traweek (Eds.), Doing Science + Culture (pp. 221-258). New York, NY: Routledge.

Barad, K. (2007). Meeting the universe halfway: Quantum physics and the entanglement of matter and meaning. Durham, NC: Duke University Press.

Barad, K. (2010). Quantum entanglements and hauntological relations of inheritance: Dis/continuities, spacetime enfoldings, and justice-to-come. Derrida Today, 3(2), 240-268.

Barad, K. (2011). Erasers and erasures: Pinch's unfortunate 'uncertainty principle'. Social Studies of Science. https://doi.org/10.1177/030631271140 6317.

Barad, K. (2012a). What is the measure of nothingness? Infinity, virtuality, justice. Documenta, 13, 1-17.

Barad, K. (2012b). Interview with Karen Barad. In R. Dolphijn \& I. van der Tuin (Eds.), New materialism: Interviews \& cartographies (pp. 48-70). Ann Arbor, MI: Open Humanities Press.

Battiste, M. (2005). You can't be the global doctor if you're the colonial disease. In P. Tripp \& L. J. Muzzin (Eds.), Teaching as activism (pp. 121-133). Montreal, QC: Queen's University Press.

Battiste, M. (2013). Decolonizing education: Nourishing the learning spirit. Saskatoon, SK: Purich Publishing.

Battiste, M., Bell, L., Findlay, I., Findlay, L., \& Henderson, J. (2005). Thinking place: Animating the Indigenous humanities in education. The Australian Journal of Indigenous Education, 34, 7-18.

Bazzul, J. (2017). From orthodoxy to plurality in the nature of science (NOS) and science education: A metacommentary. Canadian Journal of Science, Mathematics and Technology Education, 17(1), 66-71. 
Bazzul, J., \& Carter, L. (2018). (Re)considering Foucault for science education research: Considerations of truth, power and governance. Cultural Studies in Science Education, 12, 435-452.

Blaut, J. (1993). The colonizer's model of the world: Geographical diffusionism and Eurocentric history. New York, NY: Guilford Press.

Bohm, D. (1996). On dialogue. New York, NY: Routledge.

Britzman, D. P. (2003). Practice makes practice: A critical study of learning to teach. Albany, NY: SUNY Press.

Cajete, G. (1994). Look to the mountain: An ecology of indigenous education. Durango, CO: Kivaki Press.

Cajete, G. (2000). Native science: Natural laws of interdependence. Santa Fe, NM: Clear Light Books.

Cajete, G. (2015). Indigenous community: Rekindling the teachings of the seventh fire. St Paul, MN: Living Justice Press.

Carter, L. (2004). Thinking differently about cultural diversity: Using postcolonial theory to (re)read science education. Science Education, 88(6), 819-836.

Carter, L. (2005). A place for alternative readings: Can they be of use? Responding to comments on "Thinking differently about cultural diversity: Using postcolonial theory to (re)read science education.". Science Education, $89(6), 913-919$.

Carter, L. (2010). The armchair at the borders: The 'messy' ideas of borders, border zones and epistemological diversity in multicultural science education. Science Education, 94, 1-20.

Chinn, P. (2007). Decolonizing methodologies and Indigenous knowledge: The role of culture, place and personal experience in professional development. Journal of Research in Science Teaching, 44(9), 1247-1268.

Cobern, W. W., \& Loving, C. C. (2008). An essay for educators: Epistemological realism really is common sense. Science \& Education, 17, 425-447.

de Freitas, E., Lupinacci, J., \& Pais, A. (2017). Science and technology studies $\times$ educational studies: Critical and creative perspectives on the future of STEM education. Educational Studies, 56(6), 551-559.

Derrida, J. (1976). Of grammatology (G. C. Spivak, Trans.). Baltimore, MD: John Hopkins University Press.

Derrida, J. (1994/2006). Specters of Marx: The state of the debt, the work of mourning, of the new international (P. Kamuf, Trans.). New York, NY: Routledge.

Donald, D. (2012). Indigenous Métissage: A decolonizing research sensibility. International Journal of Qualitative Studies in Education, 25(5), 533-555.

Foucault, M. (1997). The politics of truth. New York, NY: Semiotext(e). 
Higgins, M. (2014). De/colonizing pedagogy and pedagogue: Science education through participatory and reflexive videography. Canadian Journal of Science, Mathematics and Technology Education, 14(2), 154-171.

Higgins, M., \& Kim, E. J. (2019). De/colonizing methodologies in science education: Rebraiding research theory-practice-ethics with Indigenous theories and theorists. Cultural Studies of Science Education, 14(1), 111-127.

Higgins, M., \& Tolbert, S. (2018). A syllabus for response-able inheritance in science education. Parallax, 24(3), 273-294.

Jackson, A. Y., \& Mazzei, L. A. (2012). Thinking with theory in qualitative research: Viewing data across multiple perspectives. New York, NY: Routledge.

Kayumova, S., McGuire, C. J., \& Cardello, S. (2019). From empowerment to response-ability: Rethinking socio-spatial, environmental justice, and natureculture binaries in the context of STEM education. Cultural Studies of Science Education, 14(1), 205-229.

Kuokkanen, R. J. (2007). Reshaping the university: Responsibility, Indigenous epistemes, and the logic of the gift. Vancouver, BC: UBC Press.

Kuokkanen, R. J. (2008). What is hospitality in the academy? Epistemic ignorance and the (im)possible gift. Review of Education, Pedagogy, and Cultural Studies, 30(1), 60-82.

Kuokkanen, R. (2010). The responsibility of the academy: A call for doing homework. Journal of Curriculum Theorizing, 26(3), 61-74.

Lather, P. (2007). Getting lost: Feminist efforts toward a double(d) science. New York, NY: State University of New York.

Latour, B. (1993). We have never been modern. Cambridge, MA: Harvard University Press.

Latour, B. (2004a). Why has critique run out of steam? From matters of fact to matters of concern. Critical Inquiry, 30(2), 225-248.

Latour, B. (2004b). Politics of nature: How to bring the sciences into democracy. Cambridge, MA: Harvard University Press.

Lewis, B., \& Aikenhead, G. (2001). Introduction: Shifting perspectives from universalism to cross-culturalism. Science Education, 85, 3-5.

Little Bear, L. (2016, June). Big Thinking and rethinking: Blackfoot metaphysics 'waiting in the wings'. Keynote address at 2016 Congress of the Humanities and Social Sciences, Calgary, Alberta.

McKinley, E. (2001). Cultural diversity: Masking power with innocence. Science Education, 85(1), 74-76.

McKinley, E. (2007). Postcolonialism, Indigenous students, and science education. In S. K. Abell \& N. G. Lederman (Eds.), Handbook of research on science education (pp. 199-226). Mahwah, NJ: Lawrence Erlbaum.

McKinley, E., \& Aikenhead, G. (2005). Comments on "Thinking differently about cultural diversity: Using postcolonial theory to (re)read science education”. Science Education, 89(6), 901-906. 
McKinley, E., \& Stewart, G. (2012). Out of place: Indigenous knowledge in the science curriculum. In B. Fraser, K. Tobin, \& C. J. McRobbie (Eds.), Second international handbook of science education (pp. 541-554). Dordrecht, NL: Springer, Netherlands.

Milne, C., \& Scantlebury, K. (Eds.). (2019). Material practice and materiality: Too long ignored in science education (Vol. 18). Switzerland: Springer.

Moulton, J. (1983). A paradigm of philosophy: The adversary method. In S. Harding \& M. B. Hintikka (Eds.), Discovering reality: Feminist perspectives on epistemology, metaphysics, methodology, and philosophy of science (pp. 149-164). Dordrecht, NL: Reidel.

Nakata, M. (2007a). Disciplining the savages: Savaging the disciplines. Exploring inscriptions of Islanders in Western systems of thought. Canberra, Australia: Aboriginal Studies Press.

Nakata, M. (2007b). The cultural interface. The Australian Journal of Indigenous Education, 36(S1), 7-14.

Patel, L. (2016). Decolonizing educational research: From ownership to answerability. New York, NY: Routledge.

Rhee, J. E., \& Subreenduth, S. (2006). De/colonizing education: Examining transnational localities. International Journal of Qualitative Studies in Education, 19(5), 545-548.

Sammel, A. (2009). Turning the focus from 'other' to science education: Exploring the invisibility of whiteness. Cultural Studies of Science Education, 4, 649-656.

Smith, L. T. (1999/2012). Decolonizing methodologies: Research and Indigenous People (2nd ed.). London, UK: Zed Books.

Smith, L. T., Maxwell, T. K., Puke, H., \& Temara, P. (2016). Indigenous knowledge, methodology and mayhem: What is the role of methodology in producing Indigenous insights? A discussion from mātauranga Māori. Knowledge Cultures, 4(3), 131-156.

Southerland, S. A. (2000). Epistemic universalism and the shortcomings of curricular multicultural science education. Science \& Education, 9, 289-307.

Spivak, G. C. (1976). Translator's preface. In J. Derrida (Ed.), Of grammatology (G. C. Spivak, Trans.) (pp. ix-lxxxvii). Baltimore, MD: Johns Hopkins University Press.

Spivak, G. C. (1988). Can the subaltern speak? In C. Nelson \& L. Grossberg (Eds.), Marxism and the interpretation of culture (pp. 271-313). Urbana, IL: University of Illinois Press.

Spivak, G. C. (1993/2009). Outside in the teaching machine. New York, NY: Routledge.

Spivak, G. C. (1994). Responsibility. boundary 2, 21(3), 19-64.

Spivak, G. C. (1999). A critique of postcolonial reason. Cambridge, MA: Harvard University Press. 
Stengers, I. (2018). Another science is possible: A manifesto for slow science. Cambridge, MA: Polity.

van Eijck, M., \& Roth, W. M. (2007). Keeping the local local: Recalibrating the status of science and traditional ecological knowledge (TEK) in education". Science Education, 91(6), 926-947.

van Eijck, M., \& Roth, W. M. (2009). Authentic science experiences as a vehicle to change students' orientations toward science and scientific career choices: Learning from the path followed by Brad. Cultural Studies of Science Education, 4(3), 611-638.

Wallace, M., Higgins, M., \& Bazul, J. (2018). Thinking with Nature: Following the contours of minor concepts for ethico-political response-ability in science education. Canadian Journal of Science, Mathematics and Technology Education, 18(3), 199-209.

Open Access This chapter is licensed under the terms of the Creative Commons Attribution 4.0 International License (http://creativecommons.org/licenses/ by $/ 4.0 /)$, which permits use, sharing, adaptation, distribution and reproduction in any medium or format, as long as you give appropriate credit to the original author(s) and the source, provide a link to the Creative Commons license and indicate if changes were made.

The images or other third party material in this chapter are included in the chapter's Creative Commons license, unless indicated otherwise in a credit line to the material. If material is not included in the chapter's Creative Commons license and your intended use is not permitted by statutory regulation or exceeds the permitted use, you will need to obtain permission directly from the copyright holder.

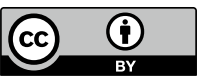

